\title{
The Figure of the Tanda in Old Javanese Literary and Epigraphical Records
}

\author{
Jiř́ijákl \\ Ruprecht Karls Universität Heidelberg, Germany \\ jiri.jakl@uni-heidelberg.de
}

\begin{abstract}
This article offers a detailed analysis of the category of men known as tanda. Widely attested in literary records and known from Old Javanese inscriptions, the function and social status of tanda has been a controversial issue. Two views pertaining to the identity of these men have been advanced so far. According to most scholars, tanda were high-status officials, often interpreted as military 'officers'. According to an alternative view, they were low-status military figures and their function was to oversee markets, or they were low-status figures associated with music and performances. This article argues that until at least $1200 \mathrm{CE}$ tanda were court-based, active combatants, who had troops of their own followers at their disposal and were responsible for the military expansion of Javanese states. By the Majapahit period they were integrated as regular troops into the progressively more hierarchical system of the professional standing army, which resulted in their reduced social status.
\end{abstract}

\section{Keywords}

Java - ancient warfare - Old Javanese literature - taṇda 
The category of men called tanda is widely attested in kakawin, epic poems written in the literary register of Old Javanese, composed in Java between the ninth and fifteenth centuries CE, and later also in Bali. Tanda are associated with the court milieu and typically figure in a military context. ${ }^{1}$ They are also mentioned in Old and Middle Javanese prose texts and have been documented in Old Javanese epigraphical records, too. The category is obviously ancient, as it is attested in the Kakawin Rämāyana, a poem composed between the second half of the ninth and the first quarter of the tenth century CE in Central Java. Most interestingly, the word tanda only rarely designates a single person: in the corpus of Javanese literature, as well as in Old Javanese inscriptional records, it is used almost invariably in the plural meaning, denoting a category of tanda. This pattern is often emphasized by the use of the particle para, which marks the plural in Old Javanese. ${ }^{2}$ I know of only two passages in which tanda is mentioned in its singular meaning; one of them, an important passage in the Kakawin Rammanyana, is analysed in the third part of this article.

The status and actual function of tanda has invited substantial scholarly attention, yet their role in Javanese, pre-Islamic society is not entirely clear. A number of scholars have suggested that tanda designates a category of court officials and/or military commanders, often interpreted, in my view rather anachronistically, as 'officers'. To give several examples, Soewito Santoso (1980, III:640) renders tanda in his edition of the Kakawin Rāmāyana as 'official'. In the same text, Robson (2015:581) interprets tanda as 'officers', but at another place in the text he leaves the word untranslated (2015:757). ${ }^{3}$ In the Deśawarnana, a court poem composed by Mpu Prapañca in 1365 CE, Stutterheim (1948: 35,67 ) renders tanda as 'reserve officer' (original Dutch: vaandrig). Pigeaud (1960, III:9) interprets tanda in the same text as 'common tandas (headmen)', and elsewhere renders it consistently as 'tandas (headmen)' (1960, III:11, 23, 101). In the same text, Robson (1995:29, 30, 37, 87) translates tanda as 'offi-

1 Originally, Old Javanese tanda seems to have denoted emblems or devices placed on war banners, seals, and other objects, identifying their bearers/users as acting in the authority of the owner of the emblem. It will become clear in the second part of this article that this original meaning of tanda motivated the use of the word as a designation of the category of military figures discussed in this study.

2 For the use of the particle para marking tanda as plural, see, for example, Ghatotkacāśraya 5.5, 48.7, and Sumanasāntaka 15.10, 19.4.

3 For the Kakawin Rämāyana 24.112, where Robson (2015:662) reads tandan instead of tanda, see a discussion in the third part of this article. 
cers'. In the Ghațotkacāśraya, a kakawin composed by Mpu Panuluh at the end of the twelfth century CE, Robson $(2016: 51,95)$ renders tanda in two places as 'guardsmen' and in one place as 'officers' (Robson 2016:279). Teeuw and Robson (2005:271,399, 457) interpret tanda in the Bhomāntaka, an anonymous kakawin composed in the second half of the twelfth century CE, as 'officers'; elsewhere in the same text, however, they leave the word untranslated. ${ }^{4}$ In the Arjunawijaya, a kakawin composed by Mpu Tantular in the late fourteenth century CE, Supomo (1977, II:187), too, leaves tanda untranslated. In the Sutasoma, another kakawin by Mpu Tantular, O'Brian (2008) leaves the term untranslated as well, and in her comments to the text she interprets tanda tentatively as 'officer' $(2008: 263)$. Worsley et al. $(2013: 111,115,179)$ translate tanda at three places in the Sumanasāntaka, a kakawin composed around 1200 CE by Mpu Monaguna, as 'court officials'; at one place in their translation we encounter 'tanda officials' (Worsley et al. 2013:297). The uncertainty of the status and actual function of the men denoted as tanda in Old and Middle Javanese texts is discernible in the gloss provided by Piet Zoetmulder (1982:1928) in his authoritative Old JavaneseEnglish dictionary:

a category of dignitaries or officials. Is it (originally): 'in charge of a "banner" or company'? It seems, however, that it does not always point to a military rank. Pigeaud renders it with 'headman'. Is it distinguished from mantri? But tanda-mantri, certainly in catus-tanda-mantri, denotes the rank of dignity (chief officer?).

Even though Zoetmulder rightly notes that the term 'does not always point to a military rank', in most instances tanda is found in a military context and denotes persons of status. Furthermore, it is clear that the identification of tanda as members of a class of professional, salaried officers would represent an anachronism in the cultural and political context of Java before $1500 \mathrm{CE}$, though I acknowledge that the rendering of tanda as 'officer' in the narrative context of Old Javanese literary fiction can be appropriate and fitting. Recently, based on his reading of selected passages of the Kakawin Rāmāyaña and Sumanasāntaka, Acri (2011) has argued that the Old Javanese tanda was a figure of low status, which had a role in ceremonial performances. In his detailed analysis of Kakawin Rāmāyaña 24.111-114, Acri has made a number of interesting associations, finding similarities between several avian characters (the allegorical kuwon bird, the manuk widwan, and manuk uyakan birds),

4 In stanza 55.8. 
the figure of the tanda, and the widu mawayan, the figure of the ambulatory performer, whom Acri identified with a Śaiva Atimārga ascetic. Literary associations between a tanda and an enigmatic kuwon bird in Kakawin Rāmāyaña 24.112, along with the participation of tanda in court performances in Sumanasāntaka 113.3, have led Acri (2011:71) to pose the interesting question of why we find tanda associated with widu both in texts and in music and performances. Acri has concluded that 'besides their official and military activities, this category of functionaries also had the prerogative to take an active role in ceremonial performances'. To further support his claim, Acri (2011:71, n. 51) points out that the Sanskrit word tandaka denotes - apart from its other meanings'juggler', tracing this word, which is unattested as a loanword in Old Javanese, to the Sanskrit verb root tand (to beat). ${ }^{5}$ In another publication, Acri (2014:29) has reiterated his claim that the tanda of pre-Islamic Java were low-status figures, bringing into his discussion one passage in the Brahmāndapurāna, an Old Javanese version of a well-known Sanskrit purānic text that can be traced to the tenth century $\mathrm{CE}$. The opening part of the Old Javanese text details an account of a feast or ritual (kārya) held by the king, in which a number of tanda (para tanda) actively participate. The staged performance described in the Brahmāndapurāna is taken as another proof that tanda were in a particular way associated with music and performances:

Those mask performances, buffooneries, dances, and vidu competitions, were intended to accompany a ritual or religious performance $(k \bar{a} r y a)$ that was attended by the king himself and tanda functionaries. The tandas we find throughout premodern Javanese history, e.g. in RK sarga 24 and 25 , where they are mocked and connected to the performing practices of a vidu (alias kuvon-bird), in Sumanasāntaka 113.3, again dancing besides vidus, and in the 14th-century Deśavarnana, which describes them as lowranking court functionaries involved in mock war-dances.

ACRI 2014:29

In total, Acri (2011, 2014) selects four passages in support of his hypothesis that a tanda was essentially a low-class functionary and performer. But even a cursory look at Zoetmulder's Old Javanese-English dictionary (1982) shows that the figure of tanda is very well represented in the corpus of Old and Middle Javanese literature, and a more detailed search reveals that the category of the tanda is

5 In his monumental Sanskrit in Indonesia, Gonda (1973:46) does not suggest tracing the Old Javanese tanda back to Sanskrit, but rather offers 'sign, mark' as the only meaning of the Old Javanese tạda. 
attested in no less than 29 Old Javanese passages, found in (at least) 12 texts. ${ }^{6}$ Apart from the fact that Acri's claim is based on a rather selective piece of evidence, two of the passages included in support of his thesis have been misread or distorted. First, nowhere in the Deśawarnana do we find tanda involved in 'mock war dances', as claimed by Acri. In a footnote, Acri (2014:29, n. 65) specifies that the passage that depicts tanda 'as low-ranking court functionaries involved in mock war-dances' is to be found in Deśawarnana 66.5, but the characters mentioned in this stanza are actually denoted as bhața, a term that in Old Javanese (as well as in Sanskrit) refers to mercenaries, a category that is not identical with the tanda. ${ }^{7}$ No doubt, tanda - like many other military figureswould engage in simulated combats, if for no other reason than as part of their military training. This is, however, no justification for conflating two otherwise different categories of military persons. ${ }^{8}$

The second passage invoked by Acri in support of his thesis that Old Javanese tanda are figures of low status is found in stanzas 113.3 and 113.4 in the Sumanasāntaka. Acri (2011:70) has associated the figure of tanda-whose low status is taken for granted rather than questioned - with the enigmatic character of a wandering widu performer who is mentioned among participants at the wedding feast of Princess Indumatī and Prince Aja. In what follows, I quote the translation of this passage by Worsley et al. (2013:297), because it is this translation on which Acri has based his arguments about the status and function of taṇạ:

6 Apart from discussing a rather narrow selection of literary texts, Acri (2011, 2014) completely disregards a substantial Old Javanese epigraphical record pertaining to tanda. As we will see below, the inscriptional record gives us a valuable insight into the status and actual function of tanda in pre-Islamic Java.

7 In the text, Acri (2011:71) actually justifies his conflation of tanda and bhata, explaining that "[i]t is not unlikely that the tandas were involved in mock "war dances" [...]. This possibility is not as remote as it may seem prima facie, for a description of "warriors" performing together with vidus and enacting a mocked war-dance aiming at causing the laughter of the public is found in the first three lines of stanza 66.5 of the Deśavarnana.' Now, the line in question (66.5c) reads: ānyāt/ (121b) bhāta mapatra yudḍ sahajan maglapglapan anghyat andani pacah (Pigeaud 1960, I:51). Robson (1995:73) interprets this line more carefully: 'Not to mention the warriors shouting challenges-naturally the ones as loud as thunderclaps gave people a fright and made them laugh'. Old Javanese bhața, a loanword from Sanskrit, is glossed by Zoetmulder (1982:224): '(Skt bhața, from bhṛta, mercenary, hired soldier, warrior, combatant) soldier, warrior (prob. of higher rank than the ordinary bala)'. For an alternative view of bhața as originally denoting a low-class soldier, compare Gonda (1973:142), who interprets Sanskrit bhața as 'soldier, servant, slave'.

8 Compare, for example, Old Javanese Wirätaparwa 16.11, where bhața(mantri) and tanda rakryan (lord's tanda) figure as two distinct categories of personnel. 
rasa bubula təriah nin räjyāpan paḍa gumərəh para ratu saha gandịin gon rojeh tabə-tabəhan apituwi para taṇ̣̂āsrañsānan midər aritan saha paḍahi gumontor lagy atry āsurak añawat para widu sadəri aywan san் tankil hyan் acarita ${ }^{9}$

(It seemed that the centre of the kingdom might split asunder because of the thundering noise

Of the kings with their gongs, cymbals and idiophones.

The more so because tanda officials in particular vied with one another, milling about in a great crowd,

With conical drums thundering as they continued to sound loudly the introductory themes for the music.

The widu performers were just then competing with one another and the tangkil hyang were telling a story.)

According to Acri (2011:70-1), "[t]he vidus here enact their comic performance together with dignitaries such as the tandas, whom OJED [1928] describes as low-ranking dignitaries with military functions'. Zoetmulder (1982:1928), however, nowhere describes tanda as 'low-ranking' dignitaries, as can be seen in his gloss of the word quoted above. ${ }^{10}$ Furthermore, Acri links the performance of tanda to that of widu, claiming that " $\mathrm{t}]$ he tandas accompany the performance of the vidus with a "thunderous noise" (gumarah) made with their drums'. But the text nowhere says that they do so; rather, the tanda are depicted here in a simulated combat, in close proximity to the 'kings' (ratu), obviously persons of high social and political standing. In his translation of this passage, Acri (2011:70) interprets the word ratu as 'vassals'. Without giving any explanation as to why he chooses to render ratu specifically as 'vassals', Acri goes against a common - and widespread-interpretation of ratu in Old Javanese as meaning either 'king' or 'queen' (Zoetmulder 1982:1522). A close reading of the text reveals the actual identity of the ratu depicted in stanza 113.3b: they are the kings invited by King Bhoja to the wedding of his sister Indumatī. We gather this from stanza 19.3, where Mpu Monaguna offers us an account of Bhoja's decision to invite other kings (ratu) to attend the wedding:

9 Sumanasāntaka 113·3-4a. Old Javanese text taken from Worsley et al. 2013:296.

10 In the footnote, Acri (2011:71, n. 48) actually quotes Zoetmulder's entry on tanda, in which nothing is said about the low status he presumes for them. 
Now there was a royal ritual to be performed under the direction of the king.

Śrī Indumatī was to be married by swayambara so that she might choose a suitable king. The king dispatched messengers to invite all those kings who were worthy of invitation. ${ }^{11}$

Clearly, Indumatī is supposed to choose 'a suitable king' (ratu sasambhave sira) from among the 'kings who were worthy of invitation' (para ratu samayogya hundanizn). We know from a detailed list in the text that the ratu invited to the svayambara of Indumatī included the kings Hemāngada, Susenā, and Pānḍa, among other well-known, mighty epic figures. I find it difficult to call these powerful men, actual or potential political allies of King Bhoja, his 'vassals', and it is clearly not the meaning intended by Mpu Monaguna in his text. Interestingly, we find the ratu performing alongside the tanda also in the Bhomantaka, a text which is nearly contemporaneous with the Sumanasāntaka. In Bhomāntaka 81.26, the phrase watzk ratu denotes the lords allied with King Kṛ̣na; in my view, the ratu depicted in the Sumanasāntaka should also be interpreted as allied kings rather than subordinated 'vassals'. Importantly, the widu are only introduced at the beginning of stanza 113.4a, only after the performance of the ratu and tanda, who seem to interact with one another, has been discussed in stanza 113.3. It is thus improbable that the tanda would 'accompany' the widu on drums, as Acri has it. The translation by Worsley et al. (2013:297) quoted above, which has the widu coupled with the tankil hyan rather than with the tanda, seems to me to do more justice to the narrative logic of the account offered in stanzas 113.3-4.

In his review of the translation of the Kakawin Rāmāyaṇa published recently by Robson (2015), Acri (2016) again discussed the enigmatic stanza 22.112, criticizing, in my view rightly, Robson's interpretation of the term tanda. In contrast to all previous readings, which read tanda inkon, Robson (2015:662) prefers to read tandan kon. Finding no explanation for the meaning of this phrase, however, Robson leaves it untranslated. In his commentary to the text, Robson (2015:705) suggests that tandan is a 'word of abuse, in view of kong', adding further that tandan is 'definitely not the same as tanda', the word for which he gives the meaning 'sign; category of dignitaries'. Acri (2016:459) expressed disagreement with Robson's word division, reiterating his previously expressed claim that we should read tanda $\dot{n} k o \dot{n}$, where Old Javanese $\dot{n} k o \dot{n}$ has a semantic parallel in Malay engkau/kau. This time, Acri (2016:46o) offers three possible mean-

11 Sumanasāntaka 19.3abc. Translation taken from Worsley et al. 2013:115. 
ings for tanda. First, the function of tanda is linked to the institution of the kuwu (initially meaning: 'makeshift fortress'), ${ }^{12}$ strongholds that Javanese rulers built on the frontiers of their mandala domains. ${ }^{13}$ The second possible interpretation, according to Acri, would be to identify tanda with tạnda, a character he discussed in some detail in one of his articles (2014:42, n. 90), but without having made any previous suggestion of synonymizing the two words. For this interpretation of Old Javanese tanda, let me quote Acri (2016:46o) in full:

As an alternative - or simultaneously valid-possibility, I have interpreted tāṇ 441), which fits in the context as I connected the vidu to a rși-type performer-cum-ascetic character appearing on reliefs of Borobudur and Prambanan.

ACRI 2014:42

This is, of course, a very attractive hypothesis, and the widu's performer and ascetic character might account for the demonstrable aspect of ritualized show or performance associated with the tanda in several passages in the Old Javanese textual corpus. But this hypothesis might also run ahead of some of the evidence, and assume things that still need to be demonstrated. The third possibility Acri considers in his interpretation of the figure of the tanda is to amend the reading of tandan $\dot{n} k o \dot{n}$ :

As a third option, I venture to speculate that tandan $\dot{n} k o \dot{n}$ is a corruption of tandak kon, where tandak, 'dance (with songs)' (Zoetmulder 1982:1929; from Sanskrit tandaka, 'juggler'? [Monier-Williams 1899:432]), could be connected to the modern Javanese tandhak, a category of singers and dancers.

It seems to me that in his interpretation of the Old Javanese tanda as a figure of low status, Acri has been influenced by Pigeaud, whom he quotes several times. Pigeaud (196o-1962) seems to be the first scholar who advanced the hypothesis that tanda were low-class, military figures. He based his arguments on a single passage in the Deśawarnana, a court poem composed in $1365 \mathrm{CE}$ by Mpu Prapañca as a eulogy of Hayam Wuruk, the king of Majapahit (r. 1350-1389 CE). In stanza 8.1, Mpu Prapañca depicts taṇda, who are assigned

12 Compare the meaning of kubu in classical Malay.

13 In a footnote, Acri (2016:46o, n. 18) gives 'personal communication' with Jiř́i Jákl as his source for this claim. 
to guard (kuməmit) the main gate of the inner quarters of the royal palace, denoted purawaktra ('palace-mouth') in the text. ${ }^{14}$ In his influential edition of the Deśawarnana, Pigeaud (1962, III:9) translates tanda in stanza 8.1 as 'headmen', and suggests in his commentary to this passage that Old Javanese tanda denotes a 'petty officer' (1962, IV:13). Further, Pigeaud draws a correspondence between the tanda depicted in the Deśawarnana and the office of the 'superintendent of markets' as documented as existing in several cities of Central Java in the eighteenth and nineteenth centuries CE. ${ }^{15}$ Rather forcefully, Pigeaud (1962, IV:13) traces the arguably economic function of the modern tandha market supervisor to the tanda 'headmen' described in the Deśawarnana:

The fact that in Majapahit the tandas mounted guard near the marketplace leads to the supposition that their function already in the 14th century was related to the market and maintaining order.

A supposed market-related function of pre-Islamic tanda, however, is not supported by any other evidence, nor is it attested in Old Javanese epigraphical records. In my view, by denoting tanda as 'petty officer', and ascribing him a low status, Pigeaud had projected the social standing of the largely ceremonial guardsmen of the modern Yogyakartan and Surakartan courts onto pre-Islamic tanda military personnel, who were active combatants, as we will see in the second part of this article. In fact, Mpu Prapañca says nothing in his text about a presumed commercially administrative aspect of the duty of the tanda. On the other hand, by depicting the tanda as standing guard over the royal palace-the sacral centre of the populous and powerful Majapahit Empire-Mpu Prapañca implies that tanda were part of the permanent royal military establishment. ${ }^{16}$ Contrary to the views proposed by Pigeaud, and more recently also by Acri, there is very substantial evidence that persons denoted as tanda cannot be identified as low-status soldiers, nor as men whose function was purely in the field of performance or ritual. On the contrary, Old Javanese literary and epigraphical records suggest that tanda were persons of high standing: professional military figures, in most, if not all, cases active combatants,

\footnotetext{
14 On the structure of purawaktra and its function, and the cultural meanings attached to this gate, see especially Stutterheim 1948:14.

15 Compare Robson and Wibisono (2002:719), who interpret tandha II as ' 1 official in charge of the market; 2 a military rank'.

16 Robson (1995:29) offers a more balanced interpretation of stanza 8.1, translating the pertinent textual sequence $\dot{n} k \bar{a}$ toriwan para tanda tan pagat aganti kuməmit $i$ karakșanin purasabha as: 'Those are the places where the officers constantly take turns at watching over the safety of the court.'
} 
and important and powerful men, who were either based directly at the royal court, staying in their own quarters and residences, or who protected and represented their lord's interests outside the (royal) court, and were based in king's fortresses $(k u w u)$ from which the royal power extended directly to rural settlements. Now let me turn to the evidence supporting this claim.

\section{$2 \quad$ Tanda as Military Figures and Their Function in Pre-Islamic Java}

One of the earliest representations of tanda in Old Javanese literature, apart from the passages in the Kakawin Rāmāyana that will be analysed in detail below, are to be found in the Ádiparwa, an Old Javanese version of the first book of the Mahābhärata, written in the late tenth century CE (Zoetmulder 1974). Janamejaya, a grandson of Abhimanyu and great-grandson of Arjuna, has organized a 'serpent sacrifice', a magic ritual to slay Takșaka, the King of Nāga and his race of serpents. As is well known, the Mahäbhärata story is recited during the occasion of this immolation. The Javanese author informs us that just before the onset of the ritual, King Janamejaya and his troops returned from a war campaign (pandonan), during which 'they had plundered the country of Takșila' (huwus manalahakon ikan deśa takșila), because Takșila refused to obey the rule of the king [Janamejaya] (tan bhaktinya ri haji). ${ }^{17}$ While giving us an account of a famous epic story, the anonymous author offers an interesting insight into the Javanese royal protocol:

maluñguh ta siren watanan pinarək de nin tạ̣da mantrinira ${ }^{18}$

(Seated in the watanan pavilion, [the king] was approached there by his tanda and mantri dignitaries.)

A number of scholars have argued that the epic Pandiawa brothers were believed to be the mythical ancestors of the Javanese kings, and the author of the Old Javanese Ádiparwa clearly represents Janamejaya as a Javanese king, who holds audiences in the watanan pavilion. Tanda and mantri, who had apparently accompanied the king on his military campaign (pandonan), are summoned to attend the audience. The term pandonan indicates that plunder, war booty, and captives were the main goal of this military opera-

17 Ādiparwa 17.4-10.

18 Ādiparwa 17.6. Old Javanese text taken from Juynboll 19o6:6. 
tion. Elsewhere in the same text we learn that the king (san prabhu) is 'protected by his tanda and mantri, all of them carrying weapons' (rinakșa de nin tanda mantrī nira makabehan padāmawa sarwasañjata). Both tanda and mantri feature in the two passages as military figures who accompany the king during his war campaign; once back in Hastinā, they are assigned to protect and attend to the king. ${ }^{19}$ Interestingly, this passage also makes a distinction between the elite tanda and mantri, and rank-and-file soldiers, denoted as bala in the text. ${ }^{20}$ The same status is attached to the royal tanda in the Wirātaparwa, an Old Javanese version of the fourth book of the Mahäbhärata. ${ }^{21}$ Denoted 'the lord's tanda' (tanda rakryan), they appear before the king in the audience hall (Juynboll 1912:16). In the Bhäratayuddha, a kakawin composed in $1157 \mathrm{CE}$ by Mpu Səḍah and Mpu Panuluh, ${ }^{22}$ we find in stanza 36.8 a description of tanda 'drawn up' (arapat) in expectation of battle: the men assemble in Śalya's residence (wìrāyatana) found inside a fortified encampment of the Korawa warriors at Kurukșetra, alongside the 'people of the court' (wwan i dalom) (Supomo 1993:201). Again, the Javanese author represents tanda as Śalya's elite combatants rather than common soldiers or low-class performers.

When we turn our attention to the texts used by Pigeaud and Acri to support their arguments discussed above, we will see that in these texts, too, tanda figure as professional, high-status military figures. In the Sumanasāntaka, apart from the passage in stanza 113.3 analysed by Acri, tanda are mentioned at several other places. In stanza 15.10, 'the tanda and mantri' (para tanda mantri) are summoned to the royal council (höman inarahakan) by King Bhoja at the moment he announces his decision to organize a swayambara (marriage by choice) for his sister, Princess Indumatī. In stanza 39.7, Mpu Monaguna represents the residence of tanda dignitaries inside the royal court of Bhoja to be comfortable enough to accommodate Prince Aja, one of the suitors of Princess Indumatī. Meeting Aja at the major road (märga) just in front of the city, King Bhoja personally accompanies his noble guest through the gate of the city, and leads him to the place assigned for his accommodation: umah nin tandāäön pinakapasanāhe nrpasuta ${ }^{23}$ (the residence of the tanda was spacious and had been prepared for the prince). ${ }^{24}$

\footnotetext{
19 Ādiparwa $52.28-34$.

20 Ādiparwa $5^{2.34}$.

21 Wirātaparwa 16.11.

22 The text is unique in the corpus of Old Javanese kakawin due to its dual authorship (Zoetmulder 1974).

23 Sumanasāntaka 39.7a. Old Javanese text taken from Worsley et al. 2013:178.

24 Worsley et al. (2013:179) translate the line umah nin tậ̣āgön pinakapasanāhe nrpasuta as follows: 'The quarters of the court officials were spacious and had been prepared for
} 
It is difficult to envisage that Prince Aja, personally accompanied to the palace complex by the king, would be housed in a low-class establishment, if tanda would represent low-status soldiers or men making their living by some type of performance. In the Bhomāntaka, in stanza 82.17, the tanda fighting for Kṛṣna are depicted riding into battle in chariots, certainly a mark of honour in the world of kakawin court poetry. Tanda are subsumed in this text under the category of 'the king's troops' (wadwā san naranātha); moreover, the anonymous author informs us that all of the tanda 'were experienced at fighting from chariots, and they all moved in formation' (tahwäpran mahawan rathāratha-rathan gatinya ya kabeh), martial skills one would not ascribe to rank-and-file soldiers, performers, or religious figures. ${ }^{25}$ In my view, one should not underestimate the power and status of elite warriors in ancient Java: with its long-standing tradition of internecine warfare, elite combatants were of crucial importance in deciding military conflicts waged by their lords. Elsewhere in the same text, in stanza 55.8 , when the court ladies discuss the possibility that they would be given in marriage to a tanda, the ladies call him rahadyan (gentleman, lord), once again a mark pointing to the high social status of tanda in ancient Java. ${ }^{26}$ In the Ghațotkacasśraya, the tanda are rewarded by being given new courtly attire (dadar) for their military services, which included guarding the royal train during a 'pleasure trip' organized by Kṛșna. ${ }^{27}$ Again, the text represents tanda as part of the watək wwan $i$ dalom (court folk); most of them are given either new attire or money to purchase new clothes, as we gather from stanzas 5.2-5. At another place in the Ghațotkacäśraya, the most trusted of the tanda, military figures Robson (2016:95) interprets as 'guardsmen', are assigned to protect a fortified encampment $(k u w u)$ in which Kṛṣna-represented in the

the prince'. The Old Javanese term umah means either 'house' or 'home' (Zoetmulder 1982:2116), and the translation advanced by Worsley and his colleagues seems to emphasize the 'communal' aspect of the tanda dwelling. There also exists, however, the term katandan, which is glossed by Zoetmulder (1982:1928) as 'the group of tandas'. It is attested in Tantri Kāmandaka 2.24b.

25 Elsewhere I have argued (Jákl 2015) that battle chariots may well have been used in pre-Islamic Java, if only as vehicles to convey elite warriors-and especially their commanders - to the battlefield, rather than in their capacity of 'shooting platforms', a function which is commonly ascribed to battle chariots in Sanskrit and Old Javanese literature.

26 This passage in Bhomāntaka 55.8 is one of only two passages known to me in which the use of the word tanda implies a singular (the second case is the metaphorical passage in Kakawin Rāmāyaṇa 24.111 discussed below). It is worth noting that both passages have in common the fact that they are presented as direct speech.

27 Ghațotkacāśraya 5.5. Robson (2016:51) renders dadar in this passage as 'presents'. For an interpretation of dadar as 'courtly attire' and for a detailed discussion of this term, see Worsley et al. 2013:197; compare also Jákl 2016:182. 
text as a king - stays with his retinue during the 'pleasure trip': sakweh san yaduwańśa tanda sakaparcaya pinakapikandal akrama (all the Yadu tribe, and the most trusted of the tanda, formed the defensive wall in proper order). ${ }^{28}$

Hardly identifiable as low-status soldiers or humble performers, the tanda depicted in this passage are represented as seasoned combatants who are trusted to stay in close proximity to the king, in their capacity of his bodyguards, alongside Kṛnna's elite Yadu warriors In my view, by associating the tanda guards with the epic Yadu warriors, Mpu Panuluh has provided an 'epic pedigree' for the Javanese tanda, a category of military figures familiar to preIslamic Javanese. Still, in the Ghațotkacāśraya, in stanza 48.7, tanda are present at a high-profile meeting between Kṛ̣ṇa, the Pānd dawa brothers and king Matsyapati at the city of King Wirāta.a. Mpu Panuluh informs us that when the major protagonists agree on attacking (dumona) the army of Duryodhana, all the tanda eagerly abide by this decision and prepare themselves for military action (para tanda sangraha).

Turning now to the Old Javanese epigraphical record, we encounter tanda in a number of inscriptions listed among the high-ranking figures. In the inscription Tulang Air II (also called Caṇ̣i Perot II), issued in $850 \mathrm{CE}$, a tanda called Maṇdi is listed second only to Lord (rakryān) Patapān. In the Kañcana inscription, issued in $860 \mathrm{CE}$, the tanda is named third in a hierarchy headed by the king (śrì mahārāja), and his three highest ministers (mahāmantri). In the Taji inscription, issued in $901 \mathrm{CE}$, the lord's tanda (tanda rakryan) are among the participants and witnesses at the sima ceremony that marks the transfer of tax rights from the ruler to the newly established temple. The tanda are involved in festive activities, eating and drinking palm wine, covering themselves with flowers, dancing, joking, and holding boar-fights and cock-fights (Matsuyama 2009). From the twelfth century CE onward-but apparently not before this period-we encounter a category of royal notables denoted as tanda rakryān rin pakira-kiran. The term can probably best be rendered as 'lord's men of [military] strategy'. According to Boechari (2012:11), these men formed the second-highest echelon of state officials, preceded in rank only by the three highest dignitaries of the state. The designation tanda rakryān rin pakira-kiran is attested in Old Javanese inscriptional record from the Kadiri until the late Majapahit period. In the fourteenth century CE, the category is also attested in Old Javanese inscriptions issued in Bali. ${ }^{29}$ In almost all instances known to me,

28 Ghațotkacāśraya 12.6c. Old Javanese text taken from Robson 2016:95.

29 See, for example, Selumbung inscription Ib.2, which informs us that the 'lord's men of [military] strategy [based] at the court' (taṇda rakryan ipakirā-kiran ijro) receive, through 
the social status of tanda is (relatively) high, and I believe the literary and epigraphic references discussed so far prove that it is not feasible to interpret Old Javanese tanda as low-class soldiers, ritual specialists, or performers, but that we must look for another interpretation that would do justice to our evidence.

Who, then, were the men known in Old Javanese texts as tanda? To answer this question, we must start by finally letting go of one well-entrenched view. Historians and scholars of Javanese literature have been too eager to accept the idea that Javanese pre-Islamic armies were centrally organized structures, with a chain of hierarchical military command and a class of professional, salaried officers, often identified with the Old Javanese term tanda. The matter is more complex and complicated, for Javanese armies and their structures evolved over time: armies were not the same in the ninth century as they were in, say, the twelfth or fifteenth centuries CE. To obtain a better insight into the social standing and function of tanda, I start with the hypothesis advanced by Zoetmulder (1982:1928) that tanda may have originally indicated the men who were 'in charge of a "banner" or company'. There are indeed several references in Old Javanese literature to a unit called satanda (literally: 'one tanda') that seems to have referred to a military unit headed by a tanda. For example, in the Krșnāyana, a kakawin composed in the thirteenth century cE by Mpu Triguna, the author describes diverse types of war banners and flags seen at the onset of the battle, saying in stanza 48.7 that the battlefield was 'completely filled with armed men, clustered around their banners' (sär sök pənuh sañjata nin satanda).$^{30}$ In pre-modern warfare, flags and banners were symbols of the military units that they represented. Tanda would thus belong to the category of words that derive in one way or another from the terms for banners and flags, so that it would be similar to the well-known term pañji (De Casparis 1975:56).

Another meaning of tanda is '[royal] seal', with the word mostly used in the Old Javanese form tinanda (with the seal attached). ${ }^{31}$ Another form, mantanda,

the agency of the military commanders (para senāpati), the king's instructions to oversee an establishment of a freehold at Salumbun (Van Stein Callenfels 1926:68).

30 Krșnāyana 48.7a. The term sañjata in this line refers to warriors, hence my translation 'armed men', rather than to 'weapons', the most common meaning of this word in Old Javanese.

The passive form tinanda seems to be known exclusively from the chancery lan- 
has been analysed by De Casparis (1956:239), who read mañtanda si maṇdi in the inscription Tulang Air II discussed above. De Casparis translates the phrase as 'the secretary: Si Mandii' ${ }^{2}$ Elsewhere, De Casparis (1956:239, n. 166) has noted that '[ $\mathrm{t}$ ] he matanda probably denotes the man who seals the letters, orders, etc., and probably writes them, too'. I would interpret tanda not specifically as a 'seal', but rather as an 'emblem'; its meaning would thus be similar to Sanskrit lañcana. Chhabra (1961-1962:41, n. 13), for one, observes that 'such lāñchhanas or heraldic devices are sometimes common to seals, banners, shields-of-arms, crests, etc. of royal houses in India from remote antiquity'. In my view, the war banners under which the tanda served in ancient Java displayed the royal emblem and thus marked, at least originally, the warriors who directly served the king. The source of utmost importance to appreciating the role and status of tanda in pre-Islamic Java is the Padləgan inscription, issued in $1116 \mathrm{CE}$ by King Bhameśwara for the benefit of the hamlets (para duwān) in Padləgan, represented by their heads $(r a \bar{m} a)$. The inscription informs us that benefits and concessions were given to villagers for their military assistance, if they: makatohängajīwitanya mamrih rin samarakārya mrasiddha pinakabala rakșa $i$ śri maharāja (put their lives at stake in the war campaign, serving as soldiers who protected His Majesty the King). ${ }^{33}$

Most importantly, we gather from the inscription that one of the major benefits the inhabitants of Padlogan were to enjoy was being freed from the forced conscription of their young men to serve in royal armies: tan katəkana räjawa denin tanda (let no tanda have the right to invade [the hamlets] to carry out a forced conscription) (Brandes 1913:152).

The passage makes it clear that tanda, as active combatants, were in charge of the conscription of peasants, and to no longer be the object of their attentions is represented in this document as a definite privilege. The inscription also suggests that tanda had the right to enter villages as they wished, and it serves as a testimony that in the twelfth century CE peasant levies represented an important part of Javanese armies. Apart from the epigraphical evidence, the Bhomāntaka and Sumanasāntaka indicate that as late as ca. $1200 \mathrm{CE}$, the term tanda designated active combatants and warriors who distinguished themselves in battles. The Bhomāntaka, in particular, clearly represents the category of tanda as consisting of elite, well-trained warriors: in stanza 73.26, taṇda are engaged in fights at the border of the lands controlled by the Yādawa

guage. For a number of instances of tinaṇda found in Old Javanese inscriptions, see Zoetmulder 1982:1929.

32 Tulang Air II B.15. See also a discussion of this attribution in Gallop 2016:136.

33 OJo 67, A.8. Brandes 1913:152. 
warriors. Elsewhere in the same text, the tanda fighting for Kṣitisuta are represented as seasoned warriors, who can be relied upon for their battle experience: pinakādhikāra para taṇ̂a sañ kṣitisutātiśaktisuyaśa ${ }^{34}$ (Ksitisuta's tạ̣da, strong and famous, were his elite troupes). ${ }^{35}$

The term suyaśa (famous) in this passage suggests that tanda personnel had already demonstrated their martial skills and military excellence in previous battles. The passage does not represent tanda as members of a class of 'officers', simply because the category of salaried military commanders was not known in twelfth-century Java. ${ }^{36}$ Most other passages pertaining to tanda in Old Javanese texts support the view that rather than representing 'officers' or 'military functionaries', by the Kadiri period tanda were (still) seen as active combatants. In the Bhomāntaka, allied kings (watək ratu) meet with Kṛṣna and his Yadu warriors and pass the orders they have received from Kṛ̣na to their tanda (tanda nira ya winarah) ${ }^{37}$ Importantly, allied kings ( $\mathrm{ratu}$ ) rather than Kṛ̣na himself muster and give orders to the tanda, for in ancient Java each king or queen ( $r a t u$ ) would have had his or her own following of tanda, who would be in command of their own small groups of troops. This seems to have been the main way that large Javanese armies were raised prior to war campaigns: regional lords relied on their personal entourage of tanda, who, for their own purposes, brought to the field their followers, often bondsmen or slaves. In another passage in the Bhomantaka, the tanda assembled at the court of Kṛṣna are evaluated according to their martial performance, demonstrated in view of other men in simulated combats. Two passages in stanzas 81.26 and 81.28 suggest that superior skills could have secured monetary gifts or a share of war captives in the war campaign for a tanda; alternatively, they would be entrusted with the supervision of a fortress $(k u w u)$ :

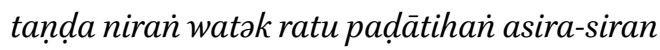

ghürnita tan pasan்kya karə⿱亠̈口̆ tabə-tabəhan ikā

len ta sañ asramen labuh aden hulun ika sabatək

ri hyun ikān katinhalana kapwa mawuwuh adəmak38

34 Bhomāntaka 85.8d. Old Javanese text taken from Teeuw and Robson 2005:466.

35 I am grateful to my anonymous reviewers for their suggestion of how to interpret this passage.

36 It is, nevertheless, entirely possible that by the twelfth century CE, if not earlier, the highest level of military commanders of Javanese armies, the men we would probably call 'generals', were salaried noblemen. Such financial arrangement was fully in place by the fourteenth century CE, as we gather from the Nawanatya (Pigeaud 1960-1962).

37 Bhomāntaka 81.25d.

38 Bhomāntaka 81.26. Old Javanese text taken from Teeuw and Robson 2005:440. 
(The tanda of the kings were all well-prepared, vying with each other, [while] boisterous din of countless percussion instruments could be heard;

Others performed simulated attacks on the square, while the whole group of their followers stayed quiet.

[They did it] in expectation that they would be seen, so that the monetary gifts might be increased.)

mvañ hana tậ̣a mākrap irikāniulah an்iñt-inat ndā krapanā kəkəh ta n aharap mahuluna makuvu ${ }^{39}$

(And there was a multitude of tanda there, engaged in combat, highly attentive;

Though assailed by many, they held on bravely, in the hope of securing slaves or a fortress.)

The context of this passage suggests that tanda were reviewed during the occasion of a pre-battle spectacle, which included a ritual of oath-taking, as well as a drill of armed forces in simulated fights (śrama). These activities culminated in festive communal eating and drinking. ${ }^{40}$ Such spectacles had a very practical purpose for the tanda: it is clear that they strove to demonstrate their martial skills in order to increase their military value, making an impression upon the king, who was supervising the event. ${ }^{41}$ The passage depicts tanda in a competitive display of martial prowess, vying with one another. Contextualizing the available evidence, I offer the hypothesis that the term tanda originally designated a warrior who had proven himself in battle and received a 'mark of honour' (tanda) in the form of an ensign that marked him as a military professional serving his lord, usually a king (ratu). Restricted use of the term tanda, invariably associated in kakawin with the military establishment of the royal court, would suggest that in Old Javanese literature the tanda were conceptualized specifically as the 'king's men', though local lords (rakryan), too, probably had their own professional tanda to serve in their armies; the designation tanda rakryan used in the Taji inscription discussed above may refer to tanda serving local lords. It seems to me that tạda rakryān i pakira-kiran originally repres-

39 Bhomāntaka 81.28ab. Old Javanese text taken from Teeuw and Robson 2005:440.

40 For oath-taking rituals, and festive drinking in the context of warfare, see Charney 2004.

41 The motif of pre-battle spectacle undoubtedly represents one of the most interesting examples of the localization and contextualization of originally Indic literary themes in kakawin poetry (Jákl 2015). 
ented an institution of 'warlords' in service to the king, who were in charge of military expansion and territorial consolidation. In the Kadiri period, tanda established themselves as a powerful category at Javanese royal and princely courts, and alongside their military careers they assumed important administrative functions in the government.

Though in most passages analysed so far the tanda do not engage in any kind of theatrical or musical performance, it cannot be denied that military signalling and martial/festive music were important tasks ascribed to tanda in Old Javanese literature, as suggested by Acri in several of his contributions. Already in the Kakawin Rāmāyana, tanda are associated with the padahi drums. In stanza 26.7, the anonymous author describes a festive welcome given in Ayodhyā to Rāma and Sìtā, who approach the city in the airborne Puṣpaka vehicle. Numerous drums are sounded, 'like the padahi used to mark time for the tanda rakryān to celebrate the month of Măgha' (kadipadahipadendẹn tanda rakryan mamāgha). ${ }^{42}$ In his work on the music of pre-Islamic Java, Kunst (1968:40) has suggested that Old Javanese padahi were most probably kettledrums, demonstrating persuasively that drums were dominant in the Central Javanese period, and remained important until the twelfth or thirteenth century CE. Thereafter, metal gongs became increasingly common, finally dominating drums in the fourteenth or fifteenth centuries CE. ${ }^{43}$ Kettledrums have a very long tradition in Southeast Asia, going back to the ceremonial use of bronze kettledrums by the Dongson notables (Bernet Kempers 1988). The ceremonial use of drums by tanda seems to be implied in Sumanasāntaka 19.4: upon receiving the orders issued by King Bhoja that his sister, Princess Indumatī, would be married by swayambara, the tanda 'make a noise like the thunder day and night, rumbling all together, answering each other in turn from all sides of the compass' (soresuk gumərəh makakratug abandun asahuran aganti lor kidul). 'Drumming up' the people for Indumatî's wedding, the tanda clearly participate in the 'spectacle of state', which in ancient Java also included military reviews, parades, and royal audiences.

42 Old Javanese text taken from Van der Molen 2015:6o1.

43 See also Kunst 1973 for the decreased popularity of drums and the increased popularity of gongs in modern Java. In the Kakawin Rāmāyaṇa and the Arjunawiwāha, two of the earliest kakawin known to us, various types of drums are the foremost musical instruments used in military signalling. The Old Javanese term gon only seems to be documented for the first time around $1200 \mathrm{CE}$, when it is attested in Sumanasantaka 146.14. The sounding summons the peasant levy and drives them to join the army in the field. Flat gongs, however, figure among trade items shipped from China to Sumatra much earlier, namely from the tenth century CE onwards (Nicolas 2011:36o). 
In sum, for the period between the ninth and thirteenth centuries $\mathrm{CE}$, tanda are best interpreted as active warriors in the service of the king or other lords, who stayed either permanently at the court or were stationed in fortresses in different parts of the realm, where they served as a tool of military expansion. Rather than representing 'officers', tanda were elite combatants who were in charge of their own followers, the men denoted as hulun sabatzk (pack of followers) in Bhomantaka 81.26.44 The power and status of the tanda may have decreased after $1222 \mathrm{CE}$, when the Kadiri kingdom became integrated into the Singhasari state; their diminished status and power is clearly reflected in sources from the fourteenth century $\mathrm{CE}$, which we shall discuss in some detail. For the study of the function and status of tanda in the fourteenth century CE we have the immensely valuable testimony of Mpu Prapañca, in the Deśawarnana. The men denoted as tanda, mentioned in several places in the text, figure among the military troops of Majapahit, where they represented an important part of the royal establishment of a standing, professional army. Some of these men, as we have seen above, were assigned to guard the major gate leading to the inner quarters of the royal palace. In stanza 9.2, Mpu Prapañca depicts the tanda and indicates their status relative to other military figures assigned to guard the royal palace:

nāhan tädinya mungw in watanan alun-alun tan/pgat lot maganti tanda mwañ gusti wadwā haji muwah ikan amwañ tuhan/ rin yawābāp mukyan் muñgwiṅ wijil/ pi kalih adika bhayañkāryyapintāpupul/sök $k^{45}$

(These are the main [troops] posted in the watanan pavilion in the square, constantly taking turns:

Tanda and gusti, the king's troops, as well as bonded troops, who are posted outside in great numbers.

The elite [troops] are stationed at the Second Gate: the eminent Bhayankaari, who guard the gate with an iron fist.)

In the first line of this stanza, the tanda are closely associated with the protection of the watanan pavilion. Interestingly, the same function is assigned to them in the passage in the Ádiparwa discussed in some detail above. In the Old Javanese version of the first book of the Mahäbhärata, taṇ $\mathbf{a}$ are also posted at

44 Teeuw and Robson (2005:441) translate hulun in this passage as 'slaves'. For the discussion of slavery/bondage and their various forms in pre-Islamic Java, see Jákl 2017.

45 Deśawarnana 9.2abc. Old Javanese text taken from Pigeaud 196o, i:8. 
the watarian pavilion, protecting the epic king Janamejaya. The Old Javanese $\bar{A}$ diparwa was written in the late tenth century CE, while the Deśawarnana was composed or finalized in $1365 \mathrm{CE}$, so that there is a gap of almost four hundred years between the two texts: the function of the Javanese tanda to protect the king-being stationed at the watarian pavilion, which seems to have served as an audience hall and a place for state officials to meet-was clearly a longstanding duty of this category of military persons. Zoetmulder (1982:2222) has conveniently summarized what we know about the watanan pavilion from its numerous descriptions in Old and Middle Javanese literature:

it appears that watanan is the place where the king gives audience. Emerging from the pura (jro, kadatwan) he takes his place there. From AgP it seems that it is a building of wood. But the courtyard is certainly also meant; it has sand, gates; a wrestling match is held there; in the centre is a mandiapa. It is possible that sthāna watanan (Udy; BY; AbhW) and bwat watanan (KY) indicate the building in the middle (cf AWj 3.3: bwat mantěn [...] mungw i těnah in watanan), which has given its name to the whole area.

It seems, then, that the major function of the Old Javanese watanan complex was to serve as a place to hold audiences. I can add one interesting detail. The earliest description of the watanan complex is found in the Kakawin Rāmāyana. In stanza 12.51 we learn that

watä̇an atiśayè lwā yeka kāinkən samudra

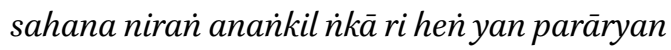
kadi ta ya kalib in lwah yan pañämbag katambak ${ }^{46}$

(The wataian complex was very broad indeed, like an ocean; All those attending the audience and who were waiting outside Were like flooding rivers that had stopped flowing and been dammed. $)^{47}$

46 Kakawin Rāmāyaṇa 12.57acd. Old Javanese text taken from Van der Molen 2015:267.

47 The phrase 'rivers [...] dammed' (lwah [...] katambak) represents, in my view, an allusion to the physical layout, or architectural structure, of the (walled?) watarian complex; in stanza 18.37 we learn that Angada, the son of Bālī, who comes to discuss with Rāwana the conditions of surrender and peace, enters the watanan 'by way of the tambak' (mahawan ta tambakmasuk). Robson (2015:441), for one, translates this passage as: '[Angada] arrived by the way of the causeway', which is certainly a possible interpretation of tambak in this context. 
From stanzas 12.58-64 we learn that the men who pour into the watanan complex are Rāwana's warriors, who bring the booty they plundered in Indra's heaven. The watanan is thus represented as a 'collection point' where tribute, plunder, and gifts flow in like rivers flow into the ocean. In stanza 12.64, Ràwana enters the watanan and sits on the bejewelled throne, from where he inspects his warriors and the men who bring in the booty. We will come back to this scene in the next section. In the Deśawarnana, the tanda are classed, along with the gusti, as 'the king's troops' (wadwā haji), military personnel who, posted at the watanan pavilion, rotate in guarding the outer gate leading to the inner quarters of the royal palace. However, the most prestigious place to stand guard, the inner gate of the palace complex (the 'Second Gate'), is protected by the Bhayankāri, the elite troops who act as the personal bodyguards of Hayam Wuruk and his family, and whose function and social status is welldocumented. It seems that by the Majapahit period the elite Bhayañkāri had resumed the most honoured duty to guard the inner apartments of the king and the main gate leading to them, while the military status of the tanda, though still relatively high, had been lowered. The Bhayankāri seem to have been the most loyal troops associated with the rise of the Sinhasari-Majapahit dynasty to power. Yet, elsewhere in the Deśawarnana, the tanda are listed among the categories of court people who accompany Hayam Wuruk in 1359 CE on his royal tour to Lumajan: 'mantri and tanda from the whole of Majapahit' (mantri tanda sa-wilwatikta).$^{48}$ Significantly, they take second place, their importance only one step below that of the king and princes of Java and their wives, who are mentioned in the same stanza. ${ }^{49}$ Another interesting passage in the Deśawarnana, stanza 85.1, gives us further information about the status and function of tanda in the fourteenth century CE:

tañgal nin் cetra tekan் balagaṇa mapulun் rahyā (130a) həm apupul mantrī mwan tạ̣da len/gusti sahana niuniweh wadwā haji tumūt mülwan் mantryākuwu mwaì juru buyut athawā wwan rin parapur ${ }^{50}$

(In the first half of the [month of] Cetra the troops gather to consult and take counsel together:

All of the mantri, tanda and gusti, as well as the king's personal troops join in,

\footnotetext{
48 Deśawarnana $17.7 \mathrm{~d}$.

49 Deśawarnana 17.7c.

50 Deśawarnana 85.1abc. Old Javanese text taken from Pigeaud 196o, i:66.
} 
Followed by the mantrī in charge of [royal] fortresses, juru and buyut, as well as the people of other cities.)

In this passage, the royal troops posted in the provinces are introduced, coming to the Majapahit capital on the occasion of the Cetra festival. Mpu Prapañca gives us a fascinating and very rare insight into the structure of the Majapahit army: high-ranking mantrī, who are in charge of provinces, come along with their military leaders (tanda and gusti). At the field of Bubat, where the Majapahit festivities traditionally took place, they are joined by the royal troops (wadwā haji), such as the Bhayañkāri. Next, the mantrī in charge of royal fortresses (mantryākuwu) arrive, followed by local representatives of the Majapahit government (juru and buyut). Apart from in the Deśawarnana, in other texts from the fourteenth century CE tanda are represented as military figures. In the Arjunawijaya, a kakawin composed by Mpu Tantular in the last quarter of the fourteenth century CE, tanda are still praised for their military skills. In stanza 3.4, they figure prominently in the army of Rāwana assembled in Lañkā. The tanda occupy the wanuntur yard, which is described as 'crowded with demon soldiers [and] elite warriors' (sök de nin asurabala wirrayoddha), 'with brave tanda, front-line combatants' (hana tanda subala pamukha). ${ }^{51}$

\section{$4 \quad$ Kumbhakarṇa's Speech: Predatory Warfare in Ancient Mataram}

One of the most intriguing passages in which we encounter tanda, and which has led several scholars to interpret this category as low-class figures, is found in Kakawin Rämāyana 24.112. The stanza is part of a long and beautiful description of revitalized Lañkā and its animal inhabitants, who experience a life in renewed harmony after the defeat of Rāwana and his rākșasa soldiers. In 1931, Walter Aichele published his study on the meaning of selected names of Javanese occupations, arguing that parts of book chapters 24 and 25 can be read as allegorical descriptions of historical events that marked Javanese politics in the period of ancient Javanese Mataram (Aichele 1931)..${ }^{52}$ Since then, a number of scholars have followed this fruitful approach. In stanza 24.112, the anonymous author of the text associates the figure of an enigmatic kuwon bird with the character called tanda and at the same time with the figure of the widu mawayan. This identification is presented by the literary character of a jalak bird (starling), in its critique of the kuwon bird:

$51 \quad$ Arjunawijaya 3.4b.

$5^{2}$ See also Damais 1970. 
sambegā nin kuwoì tekana hinan்ən-an்ən donyān pamajahi

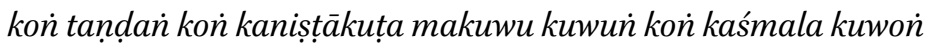
tan pomah tā katṛṣnān laku widu mawayan் ko m gunya saguna $a^{53}$

(The disposition of the kuwon over there is to concentrate his thoughts, for his aim is to kill!

You, the tanda! You have a miserable stronghold, a fortress in a hole! You are a wretch, kuwori!

Homeless, unloved, acting like a wayan-performing widu, endowed with magical powers!)

In the second line, the kuwor bird is thus allegorically identified as a tanda, who is depicted in a derogatory way as a person who lives in a 'hole' (kuwuñ) instead of being in charge of a fortress (akuta). The third line informs us that the kuwor leads a life of an unsettled, perambulatory storyteller (widu mawayan) ${ }^{54}$ who is said to be endowed with magical powers. Though scholars have rendered this line in different ways, the intended association of the character in question with low status, and with the miserable place in which he has to live, is very clear. Acri (2011:62), for one, translates the second line of stanza 24.112 as follows: 'You are a tanda! You have a very mean "palace", living in holes in the ground! You are stained, kuvon!' Robson (2015:662) translates the same line as: 'You tandang! You low creature! With a fort and with a hollow as lodging, you vile kuwong!'55

It is this satirical passage that has led several scholars to claim that the status of tanda - whoever is denoted by this term — must be low. Aichele (1969:133) has rendered the tanda in this passage as a 'Landstreicher' (vagabond), which is indeed an apt designation for a figure-allegorically represented as a perambulatory kuwon bird — wandering without a permanent place to stay. How, then, does the image of the humble, wretched tanda (depicted in stanza 24.112) fit with our finding that the tanda were high-status warriors, military chiefs, and figures of the royal administrative hierarchy? As I see it, the literary image in stanza 24.112 is consciously distorted through a parody: the author of the

53 Kakawin Rāmāyaṇa 24.112bcd. Old Javanese text taken from Van der Molen 2015:542.

54 The figure of the widu mawayan has been interpreted by several scholars as a dalang, a performer of shadow theatre (Santoso 1980; Robson 2015). However, I would be very cautious about specifically identifying it as such. Acri (2014:62) translates widu mawayain more carefully as 'vagabond performer, a wayang-player'.

55 Robson 2015:662. For Acri's critique of Robson's translation of this line, see Acri 2016:4596 o. 
Kakawin Rāmāyana meant to criticize the high-ranking tanda military chiefs of Rāwaṇa, the same men who figure prominently in stanza 22.35. Aichele (1969), Acri (2011), and Robson (2015) disregard the passage in stanza 22.35 in their discussion of the figure of the tanda. Yet, stanza 22.35 helps us to identify this figure and its role in the Kakawin Ràmāyana. As we will see below, the correspondences are actually complex and go beyond the figure of the tanda. In stanza 22.35, never analysed in detail, we encounter the men called tanda in a speech delivered by Kumbhakarnaa, a younger brother of Rāwaṇa. ${ }^{56}$ Awakened from his sleep, the giant rākșasa first finishes his gargantuan breakfast and then proceeds to meet Rāwaṇa. Though not stated explicitly, their meeting occurs at the watanan complex, as all other important audiences and meetings at Lankā depicted in the text. ${ }^{57}$ Rather than taking his brother's side, Kumbhakarna lectures him sternly on the śāstric norms for the righteous exercise of royal power, criticizing Rāwana for being unwise and blinded by his lust for power in opposing Rāma. In a bold speech, a sharp critique is launched against the tanda personnel serving to Rāwaṇa:
tậ̣̂nta ya hārohara rāt
utpāta pati pràn-prañiya
aglah midușeñ tan padușa ${ }^{58}$

(Your tanda are a menace to the world!

They are always keen on waging wars,

Finding delight in punishing sinless people.)

$5^{6}$ Zoetmulder (1982) does not list this particular reference to tanda.

57 In stanza 13.15, Wibhīṣaṇa meets Rāwaṇa, who is seated on his bejewelled throne, at the wataian. In stanza 18.12, Rāwana's spies meet their lord at the watanan to report on the battle preparations of Rāma and his simian soldiers. In stanza 18.38, Angada, the son of Bālī, enters the watanan to discuss the possible conditions of peace between Rāwana and Rāma. In stanza 19.35, Rāwaṇa's general Wirūpakșa orders his elite troops to protect the watanian at all costs, bringing all the weapons inside the watanan and attack all Rāma's soldiers who would possibly come there. It is in this passage that the watanan is represented as the most sacred and important place in the whole palace complex. Was the treasury possibly part of the watarian complex? We have seen above that the plunder was carried there, and the metaphorical reference in stanza 12.57 (where the watanan is compared to an ocean) to 'its towers, perfectly built and extraordinary' (gupura ya paripūrñāpūrwa), which are represented as 'being its cliffs' (yekā karainnya), certainly suggests that the watanan complex included high-rising, solidly built masonry structures.

$5^{8} \quad$ Kakawin Rāmāyaṇa 22.35bcd. Old Javanese text taken from Van der Molen 2015:482. 
sañ śrești linunțanya hala

mās donya dadī don rasikā

melik mulati $\dot{n}$ wan rahayu

mahyun ikanaí śila salah ${ }^{59}$

(Badly they extort the honourable merchants,

Only gold is what they are seeking;

Abhorring seeing good people,

[But] taking delight in misconduct.)

The taṇda of Rāwaṇa are depicted in Kumbhakarṇa's speech as immoral, unscrupulous, and conspicuously powerful men, who misuse the support of their lord for their own material gains. It is difficult to consider these greedy tanda as low-status dignitaries invested with only limited power, that is, as the humble 'doorkeepers' or market attendants envisaged by Pigeaud (1962, IV:13) in his reading of the Deśawarnana. Quite the contrary, Kumbhakarna depicts the tanda of Rāwana's court as powerful military figures who busy themselves with raids and wars (pati pran-prani), pillaging the country, and extorting money from merchants (san śrești). In his fiery and conspicuously open speech—badly received by his older brother-the giant Kumbhakarna identifies the tanda as the source of Rāwana's problems, and their misconduct as the reason of his ultimate defeat in the war against Rāma. Representing high-status court figures, the men with whom Rāwana spends his days drinking and carousing - the tanda - are subjected to a harsh moral and social critique. In my view, the institution of the tanda can be criticized in the text because Rāma, an arch enemy of Rāwaṇa, does not have any corresponding taṇda in his army, which is composed mostly of Sugrīwa's simian soldiery. Only in stanza 26.22a, the tand a serving to Bharața, Rāma's brother, are introduced for the first time, when they welcome Rāma back in Ayodhyā. These men, however, took no part in the war against Rāwaṇa, for they are serving to Bharața, whose troops were not engaged in this war. Importantly, they seem to ride on elephants and horses, certainly a sign of their high status, and Robson (2015:760), for one, has translated the phrase tanda rakryan as 'officers and nobles', as we have seen above.

Viewed from this perspective, it is now easier to understand the links drawn between the tanda and the figure of the kuwon bird in stanza 24.112 of the Kakawin Rāmāyana. The famous Aśoka grove suffered serious damage at the

59 Kakawin Rāmāyaṇa 22.36. Old Javanese text taken from Van der Molen 2015:482. 
four limbs of Hanumān, as we gather from stanzas 8.214-215, and it was completely devastated in the final stage of the attack on Lankā, as we learn in stanzas $23.34-35$. In stanza 24.112 , however, the author represents a magically revitalized Aśoka grove, which represents, at least symbolically, the centre of a revitalized kingdom, where law and order prevail. A number of scholars have argued that the birds and animals introduced in this passage are depicted as living in renewed harmony in the nearly paradisiacal conditions of a revitalized Lankā, where the former rākșasa demons seem to thrive. The poet describes Rāwana's previously terrible rākșasa warriors, who have now been miraculously transformed into virtuous characters, as already noted by Hooykaas (1958:265):

After the restoration of Dharma, however, our rākșasas become saints by putting an end to their vexations and preferring the company of virtuous men $[\ldots]$. Animals which normally pray upon each other now live peacefully side by side, thoroughly enjoying the fortunate opportunities bestowed upon them; they only tease one another.

However, the teasing detected by Hooykaas has a deadly point, as we have seen above: the figure of the kuwon bird is revealed to be a warrior, a tanda who is 'willing to kill', and a faithful servant of the now-dead Rāwana, one of the men whom Kumbhakarna censured in his speech as a 'menace to the world'. ${ }^{60}$ The allegorical associations between the tanda military personnel and the kuwon bird are complex, as recognized by Acri, and some of them are probably lost on us. There is not only the shared participation in music and acting performances, as observed by Acri (2011:71), but also, and most importantly, a predatory character that is shared by the two figures: while the kuwon bird is characterized in a number of Old Javanese texts by its carnivorous diet (see above: his task is to kill!'), the tanda, a warrior by profession, is clearly a human 'killer', who is cruel and unforgiving, as we learn in stanza 22.35, quoted above. It seems to me that after the loss of Lankā, a daring tanda seems to plan to establish a new stronghold $(k u w u)$ as a base from which to wage war against the newly appointed ruler of Lankā.

To summarize this exploration of the character of the tanda in the Kakawin Rāmāyaña, we can conclude that the tanda is not a man of low status, as Pigeaud and Acri have surmised. He nevertheless makes two contrasting appearances in this kakawin, calculated to achieve both mockery and a social

6o Kakawin Rāmāyaṇa 22.35. 
critique. As military personnel serving to Rāwaṇa, taṇda are depicted in stanzas $22.35^{-3} 6$ as rākșasa warlords, lusting for gold and booty, still in full power, well-nested in the stronghold of Lankā. On the contrary, in stanza 24.112, the figure of the tanda (allegorically associated with the kuwon bird) is represented as a wandering, lord-less warrior, a former warlord, who is cherishing the hope of establishing a new stronghold from which to launch predatory raids. The social, and presumably political situation of Rāwana's former tanda military personnel has changed: now they are doomed to live as scared individuals in hiding, wandering in the paradise of Lañkā.

This article has discussed in detail the category of men denoted as tanda, which is widely attested in Old Javanese literature, especially in kakawin. Invariably, tanda are associated with the court milieu and typically figure in a military context. They are also mentioned in Old and Middle Javanese prose texts and have been documented in Old Javanese epigraphical records, too. The function and social status of the Old Javanese tanda have been the subject of substantial scholarly attention, and most scholars have suggested that the term tanda indicates court officials and/or military commanders, and is often interpreted as 'officers'. Even though Zoetmulder (1982:1928) has rightly noted that the term does not always point to a military rank, in most instances tanda are found in a military context where they enjoy high status. Yet, several scholars have argued that tanda were low-status figures and represented either rank-and-file soldiers, or functionaries and performers.

In this article, 24 Old Javanese passages in which tanda feature have been analysed, apart from epigraphical evidence. In sixteen passages, tand $a$ are represented as military figures of high status; ${ }^{61}$ in four passages, they are depicted as figures of high status, but their military function cannot be ascertained from the text. ${ }^{62}$ In three other passages, tand $a$ are represented as military figures, while their social status is not entirely clear. ${ }^{63}$ Only in two passages are their military function and social status not clear enough to allow for any con-

61 These passages include Kakawin Rāmāyaṇa 22.35, 26.22a; Ādiparwa 17.6, 52.34; Wirāțaparwa 16.11; Bhāratayuddha 36.8; Ghațotkacāśraya 5.5, 12.6, 48.7; Bhomāntaka 81.25-26, 81.28, 82.17; Sumanasāntaka 113.3; Deśawarnana 17.7, 85.1; and Arjunawijaya 3.4.

62 These passages include Bhomāntaka 55.8, 82.36 and Sumanasāntaka 15.10, 39.7.

63 These passages include Bhomāntaka 73.26 and Deśawarnana 8.1, 9.2. 
clusions to be drawn. ${ }^{64}$ All in all, in 20 out of 24 passages analysed in this study, tanda are represented as figures of high social status, and in 19 out of 24 passages they are depicted as military figures. A hypothesis has been offered that between the ninth and thirteenth centuries CE, tanda were not 'officers', but rather active warriors in the service of the king or another lord, who stayed either at the court or were stationed in fortresses owned by the king or lesser lords in different parts of the realm. Tanda seem to have been in charge of their own followers, the men denoted as hulun sabatzk in Bhomāntaka 81.26. Old Javanese epigraphical evidence, too, suggests that the tanda were figures of relatively high status, though their military function is only rarely apparent in epigraphical records. An important document is the inscription issued in $1116 \mathrm{CE}$ by King Bhameśwara for the benefit of the hamlets in Padlegan; from this inscription we gather that the tanda were in charge of forced conscription and that to be freed from their attention seems to have been a privilege in ancient Java. From the twelfth century CE onward-but apparently not before this period-we encounter a category of royal notables denoted as tanda rakryān rin pakira-kiran. This phrase can probably best be rendered as 'lord's men of [military] strategy'. These men formed the secondhighest echelon of state officials, preceded in rank only by the three highest dignitaries of the state. It is unclear if these men were active combatants or, rather, salaried officers. The designation tanda rakryān rin pakira-kiran is attested in Old Javanese inscriptional record until the late Majapahit period. It seems that in the fourteenth century CE the importance of the category of tanda diminished, though at least some of the men were still active combatants.

\section{Acknowledgements}

I wish to thank two anonymous reviewers for their detailed comments on the first draft of this article, and for helpful suggestions on how to improve the argument advanced in this paper.

64 Kakawin Rāmāyaṇa 26.7; Sumanasāntaka 19.4. The very specific and allegorical passage in Kakawin Rāmāyaṇa 24.112 has not been counted in this list, while I believe that the reference is to the court tanda already mentioned in stanza 22.35 . 


\section{References}

Acri, Andrea (2011). 'More on birds, ascetics and kings in Central Java: Kakavin Rāmāyana, 24.111-115 and 25.19-22', in: A. Acri, H. Creese and A. Griffiths (eds), From Laìkā eastwards; The Rāmāyaṇa in the literature and visual arts of Indonesia, pp. 53-91. Leiden and Boston: Brill.

Acri, Andrea (2014). 'Birds, bards, buffoons and Brahmans: (Re)Tracing the Indic roots of some ancient and modern performing characters from Java and Bali', Archipel 88:13-70.

Acri, Andrea (2016). 'Editing and translating the Old Javanese Kakavin Rāmāyaṇa', Bulletin de l'École française d'Extrême-Orient 102:451-65.

Aichele, Walter (1931). 'Oudjavaansche beroepsnamen', Djåwå 11:147-58.

Aichele, Walter (1969). 'Vergessene Metaphern als Kriterien der Datierung des altjavanischen Rāmāyaṇa', Oriens Extremus 16:127-66.

Bernet Kempers, A.J. (1988). The kettledrums of Southeast Asia: A bronze age world and its aftermath. Rotterdam and Brookfield: Balkema.

Boechari (2012). Melacak sejarah kuno Indonesia lewat prasasti / Tracing ancient Indonesian history through inscriptions. Jakarta: Kepustakaan Populer Gramedia.

Brandes, J.L.A. (1913). Oud-Javaansche oorkonden. Nagelaten transscripties van wijlen Dr. J.L.A. Brandes. Uitgegeven door Dr. N.J. Krom. Batavia: Albrecht \& Co./'s Gravenhage: Martinus Nijhoff.

Casparis, J.G. de (1956). Prasasti Indonesia II: Selected inscriptions from the 7 th to the gth $^{\text {th }}$ century AD. Bandung: Masa Baru.

Casparis, J.G. de (1975). Indonesian palaeography: A history of writing in Indonesia from the beginning to $c$. A.D.150o. Leiden: Brill.

Charney, Michael W. (2004). Southeast Asian warfare, 1300-1900. Leiden: Brill.

Chhabra, B.Ch. (1961-1962). 'Seals in ancient India', The Indian Archives 14:36-49.

Damais, Louis-Charles (1970). Répertoire onomastique de l'épigraphie javanaise (jusqu'à pu Siñdok Śrī İśānawikrama Dharmottungadewa). Paris: École française d'ExtrêmeOrient.

Gallop, Annabel T. (2016). 'The early use of seals in the Malay world', Bulletin de l'École française d'Extrême-Orient 102:127-63.

Gonda, Jan (1973). Sanskrit in Indonesia. New Delhi: International Academy of Indian Culture.

Hooykaas, Christiaan (1958). 'The paradise on earth in Lěṅkā (oJR XXIV. 87-126)', Bijdragen tot de Taal-, Land- en Volkenkunde 114-3:265-91.

Jákl. Jiř́ (2015). 'Bhoma’s Kitchen: Food Culture and Food Symbolism in Pre-Islamic Java', Global Food History 1(1):33-58.

Jákl, Jiřri (2016). 'The folding book format (concertina) in pre-Islamic Java: Revisiting the Old Javanese term lapihan', Bulletin de l'École française d'Extrême Orient 102:165-93. 
Jákl, Jiři (2017). 'Black Africans on the maritime Silk Route: Jgrgi in Old Javanese epigraphical and literary evidence', Indonesia and the Malay World 45-133:1-18.

Juynboll, H.H. (19o6). Ādiparwa: Oudjavaansch prozageschrift.'s Gravenhage: Martinus Nijhoff.

Juynboll, H.H. (1912). Wirāțaparwa. Oudjavaansch prozageschrift. 's Gravenhage: Martinus Nijhoff.

Kunst, Jaap (1968). Hindu-Javanese musical instruments. Second, revised and enlarged edition. The Hague: Martinus Nijhoff.

Kunst, Jaap (1973). Music in Java: Its history, its theory and its technique. Third, enlarged edition. Vol. 1. The Hague: Martinus Nijhoff.

Matsuyama, Akira. 2009. Traditional dietary culture of Southeast Asia: Its formation and pedigree. London and New York: Routledge.

Molen, Willem van der (2015). Rāmāyaṇa: The story of Rāma and Sütā in Old Javanese. Romanized edition. Tokyo: Research Institute for Languages and Cultures of Asia and Africa, Tokyo University of Foreign Studies.

Monier-Williams, M. (1899). Sanskrit-English dictionary. Oxford: Clarendon Press.

Nicolas, Arsenio (2011). 'Early musical exchange between India and Southeast Asia', in: P-Y. Manguin, A. Mani and G. Wade (eds), Early interactions between South and Southeast Asia: Reflections on cross-cultural exchange, pp. 347-69. Singapore: Institute of Southeast Asian Studies.

O'Brian, Kate (2008). Sutasoma; The ancient tale of a Buddha-prince, from 14th century Java by the poet Mpu Tantular. Bangkok: Orchid Press.

Pigeaud, Th.G.T. (196o-1962). Java in the fourteenth century: A study in cultural history. The Nagara-Kèrtagama by Rakawi Prapañca of Majapahit, 1365AD. The Hague: Martinus Nijhoff. [Four vols.]

Robson, S.O. (1995). Deśawarṇana (Nāgarakṛtāgama) by Mpu Prapañca. Leiden: KITLV Press.

Robson, S.O. (2015). The Old Javanese Rāmāyana: A new English translation with an introduction and notes. Tokyo: Research Institute for Languages and Cultures of Asia and Africa, Tokyo University of Foreign Studies.

Robson, S.O. (2016). The kakawin Ghațotkacāśraya by Mpu Panuluh. Tokyo: Research

Institute for Languages and Cultures of Asia and Africa, Tokyo University of Foreign Studies.

Robson, S.O. and Singgih Wibisono (2002). Javanese-English dictionary. With the assistance of Yacinta Kurniasih. Hongkong and Singapore: Periplus Editions (HK).

Santoso, Soewito (1980). Ramayana Kakawin. New Delhi: International Academy of Indian Culture. [Three vols.]

Stein Callenfels, P.V. van (1926). 'Epigraphia Balica I', Verhandelingen van het Koninklijk Bataviaasch Genootschap van Kunsten en Wetenschappen 66-3:1-70.

Stutterheim, W.F. (1948). De kraton van Majapahit. 's Gravenhage: Martinus Nijhoff. 
Supomo, Suryo (1977). Arjunawijaya: A kakawin of Mpu Tantular. Volume 2: Translation. The Hague: Martinus Nijhoff. [Two vols.]

Supomo, Suryo (1993). Bhāratayuddha: An old Javanese poem and its Indian sources. New Delhi: International Academy of Indian Culture and Aditya Prakashan.

Teeuw, A. and S.O. Robson (2005). Bhomāntaka: The death of Bhoma. Leiden: KITLV Press.

Worsley, P., S. Supomo, T. Hunter and M. Fletcher (2013). Mpu Monaguna's Sumanasāntaka: An Old Javanese epic poem, its Indian source and Balinese illustrations. Leiden: Brill.

Zoetmulder, Piet J. (1974). Kalangwan: A survey of Old Javanese literature. The Hague: Martinus Nijhoff.

Zoetmulder, Piet J. (1982). Old Javanese-English dictionary. With the collaboration of S.O. Robson. 's Gravenhage: MartinusNijhoff. [Two vols.] 